\title{
LITHOLOGY OF THE PROFUNDAL SEDIMENTS IN SLUPIAŃSKA BAY (WIGRY LAKE, NE POLAND) - INTRODUCTION TO INTERDISCIPLINARY STUDY
}

\author{
JACEK RUTKOWSKI, KATARZYNA KRÓL and JADWIGA SZCZEPAŃSKA \\ Faculty of Geology, Geophysics and Environmental Protection, University of Science and Technology, \\ Mickiewicza 30, 30-059 Cracow, Poland
}

Received 22 December 2006

Accepted 13 February 2007

\begin{abstract}
In this paper, a lithological study taking into account trace metals of the profundal sediments from Słupiańska Bay in Wigry Lake is presented. A profile $5.26 \mathrm{~m}$ long has sandy muds at the bottom and moving upwards layers of calcareous gyttja, lacustrine chalk, and again calcareous gyttja are present. The profile is continuous, typical for the sediments of NE Poland formed from Allerøde to recent time. The results of the lithological analysis were correlated with results of high-resolution seismic survey. The results together with radiocarbon dating are part of interdisciplinary complex research comprising paleobiological study of pollen, Cladocera, diatom successions and human activity, which will be published in successive papers.
\end{abstract}

Keywords: Lake deposits, Wigry Lake, Holocene, trace metals

\section{INTRODUCTION}

The aim of this research is a complex analysis of changes of natural environment since Allerøde through the whole Holocene until recent times. As the object of research Wigry lake in NE Poland was chosen (Fig. 1).

This lake is the largest one in Suwałki Lakeland. Its physiographic and natural conditions are generally well known (Zdanowski, 1992) together with its lithology, sedimentation of its deposits (Rutkowski et al., 2002; Rutkowski, 2004) and the problem of trace metals (Prosowicz and Helios-Rybicka, 2002; Migaszewski et al., 2003; Prosowicz, 2006). Geological conditions of the lake sediments and their later deformations were determined by means of high-resolution seismic (seismoacoustic) survey (Rutkowski et al., 2002a and 2005). Wigry Lake is one of the few lakes in Poland with contemporaneous carbonate sedimentation. Because of its natural values Wigry Lake was "adopted" in 1998 by the International Association of Theoretical and Applied Limnology (SIL "Lake Adoption" Project; Kamiński, 1999).

The research comprises physiographic features of Wigry Lake, lithological analysis and some geochemical

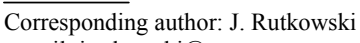

e-mail: jrutkowski@mpoczta.net

ISSN 1897-1695 (online) (C) 2007 GADAM Centre,

Institute of Physics, Silesian University of Technology.

All rights reserved. data from a $5.26 \mathrm{~m}$ long profile of lacustrine deposits from the drilling WZS-03. Other analyses of lacustrine sediments of Wigry Lake are presented in following papers: Kupryjanowicz (2007), Piotrowska et al. (2007) and Zawisza and Szeroczyński (2007).

\section{SITE DESCRIPTION}

Wigry Lake is located in the Suwałki Lakeland (NE Poland) and it is the fifth largest lake $\left(21.2 \mathrm{~km}^{2}\right)$ in NE Poland. The degree of coastline development is very high (4.35), and the lake bathymetry is fairly complicated. Distinct shallows and narrowings divide the lake into five basins, differing in physiographic characteristic. Wigierki Bay and Szyja Basin are of furrow type (Fig. 1), with the depth up to $73 \mathrm{~m}$ at the width below $1 \mathrm{~km}$. Bryzgiel and Zakatowski Basins are of morainic type. They are broad (more than $2 \mathrm{~km}$ ), and have numerous near-shore and central shallows and the depths up to $50 \mathrm{~m}$. Wigry Basin (Northern) are partly of morainic and partly, in SW part, of furrow type.

Wigry Lake lies in the moderate climate zone with some continental influences. The average summer temperature is $17^{\circ} \mathrm{C}$, and average winter temperature is $-4,2^{\circ} \mathrm{C}$. Average annual precipitation is $581 \mathrm{~mm}$ with fluctuation from $334 \mathrm{~mm}$ to $829 \mathrm{~mm}$. Main wind direc- 


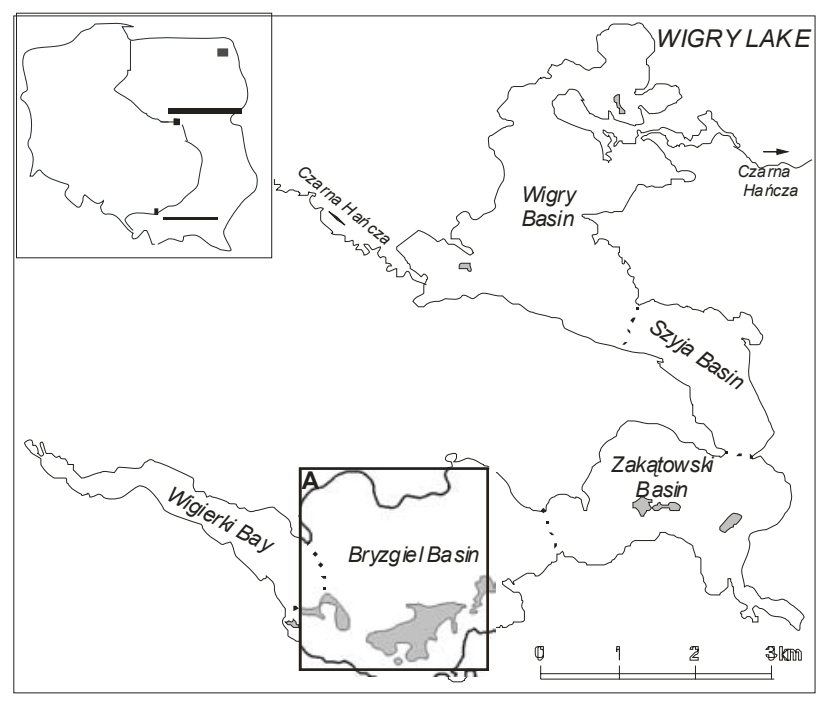

Fig. 1. Map of the Wigry Lake. Shadowed area - islands. Area in rectangle $A$ is enlarged on Fig. 3.

tions are SW, W, NW and SE. Ice cover on the lake surface appears usually in the end of December and melts in March, but during last years there was no ice cover at all.

Lake Wigry is principally a mezotrophic lake fed by the Czarna Hańcza and the Wiatrołuża rivers (Bajkiewicz-Grabowska, 1992) that fall into Northern Basin. Underground flow and precipitation also markedly contribute, mainly in the other basins. Wigry is a dimictic lake with summer and winter stagnation and spring and autumn mixion. Thermal stratification observed in the middle of Bryzgiel Basin during the maximum of summer stagnation is illustrated in Fig. 2. Water temperatures in epilimnion (water depth down to $4-5 \mathrm{~m}$, maximum $8 \mathrm{~m})$ reach $24^{\circ} \mathrm{C}$. Beneath, in the metalimnion $(8-14 \mathrm{~m})$ the temperatures rapidly decrease. In hypolimnion, at the depth below a dozen or so meters, water temperatures are permanently low and just above the bottom in the profundal part of the lake reach $4-6^{\circ} \mathrm{C}$. The oxygen condi-

\begin{tabular}{rr}
\hline Total & 354.1 \\
mineralization & \multicolumn{1}{c}{} \\
\hline $\mathrm{Ca}^{2+}$ & 57.92 \\
$\mathrm{Mg}^{2+}$ & 16.45 \\
$\mathrm{Na}^{+}$ & 7.57 \\
$\mathrm{~K}^{+}$ & 1.97 \\
$\mathrm{HCO}_{3}^{2-}$ & 218.58 \\
$\mathrm{SO}_{3}^{2-}$ & 24.56 \\
$\mathrm{Cl}^{-}$ & 13.1 \\
\hline
\end{tabular}

Table 1. Main chemical components (in $\mathrm{mg} / \mathrm{dm}^{3}$ ) of near bottom water.

tions of bottom water in this part of the lake during summer stagnation are rather bad, and even anoxic. The value of $\mathrm{pH}$ in hypolimnion water is ca. 7.3 and electric conductivity ca. $0.346 \mathrm{~S} / \mathrm{cm}$. In the surface water, $\mathrm{pH}$ is much higher (up to 8.7) and conductivity lower $(0.283 \mathrm{~S} / \mathrm{cm})$. Main chemical components (in $\left.\mathrm{mg} / \mathrm{dm}^{3}\right)$ of hypolimnion water (at temperature ca. $6^{\circ} \mathrm{C}$ ) are shown in Table 1.

The surface water contains lower amounts of $\mathrm{Ca}^{2+}$ and $\mathrm{HCO}_{3}{ }^{2-}$, due to its higher temperature. The most important component of Wigry water is $\mathrm{Ca}^{2+}$, which comes from the dilution of Pleistocene deposits rich in carbonates.

The drilling WZS-03 was done on 13.07.2003 at the point of geographic coordinates $\mathrm{N} 54^{\circ} 01.053^{\prime}$ and $\mathrm{E} 23^{\circ} 03.085^{\prime}$, determined by GPS. It was situated in the southern part of the lake, in Bryzgiel Basin, and precisely in the Słupiańska Bay in the western part of this basin. This bay is large with a broad connection with Bryzgiel Basin. It is fed by water coming from Wigierki Bay (ca. $15 \times 10^{6} \mathrm{~m}^{3}$ annually). Areas surrounding the bay are forested and a Phragmites community covers $1 / 3$ of the coastline. Direct surrounding of the Stupiańska Bay is built by glacial and fluvioglacial deposits from the last glaciation. They form an uneven upland, which rises steeply a dozen or so meters above the lake level. At its feet are lake sands and gravels, stretching as a narrow path along the shore. In the NW part of the bay surrounding there is a peat-bog present. The main components of
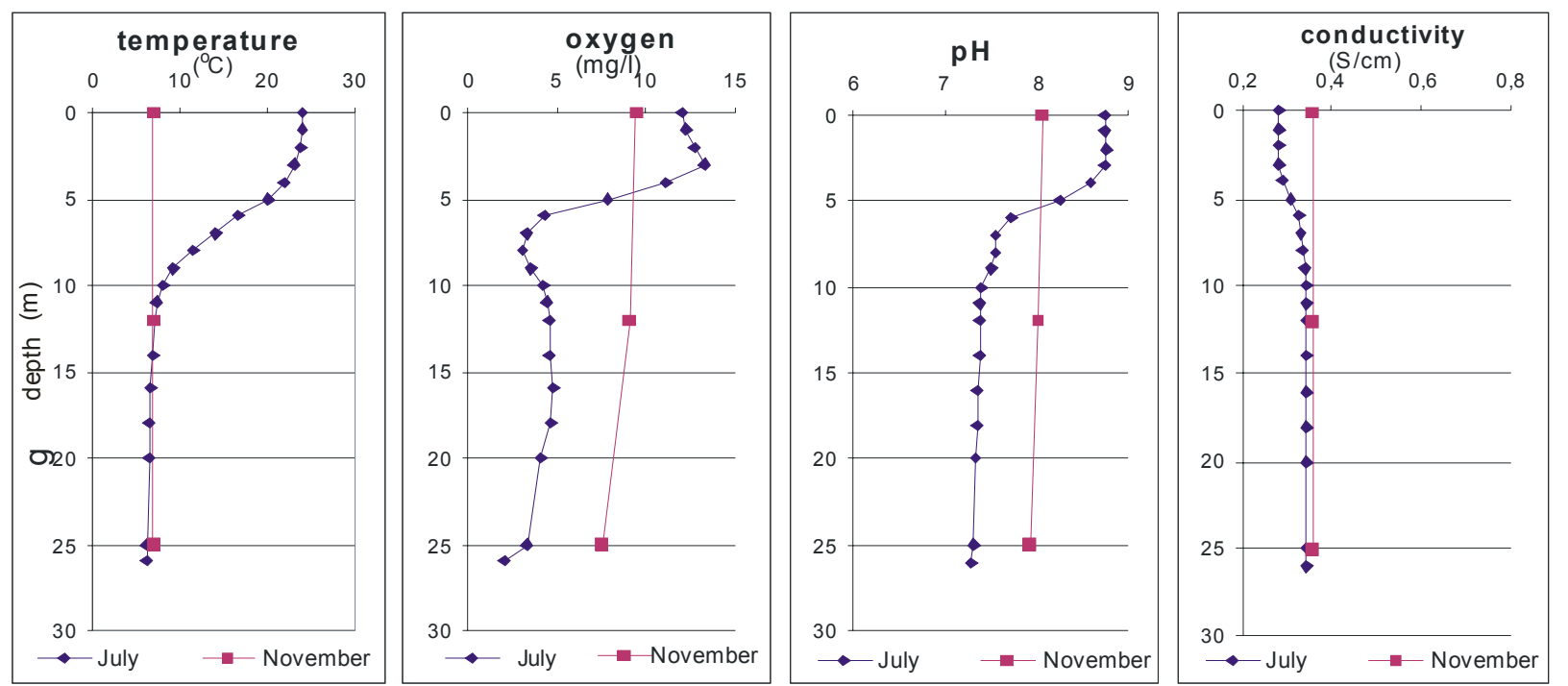

Fig. 2. Main features of the lake water in the central part of Bryzgiel Basin during summer stagnation (July 26. 2006) and in autumn mixion (November 10, 2006y). 


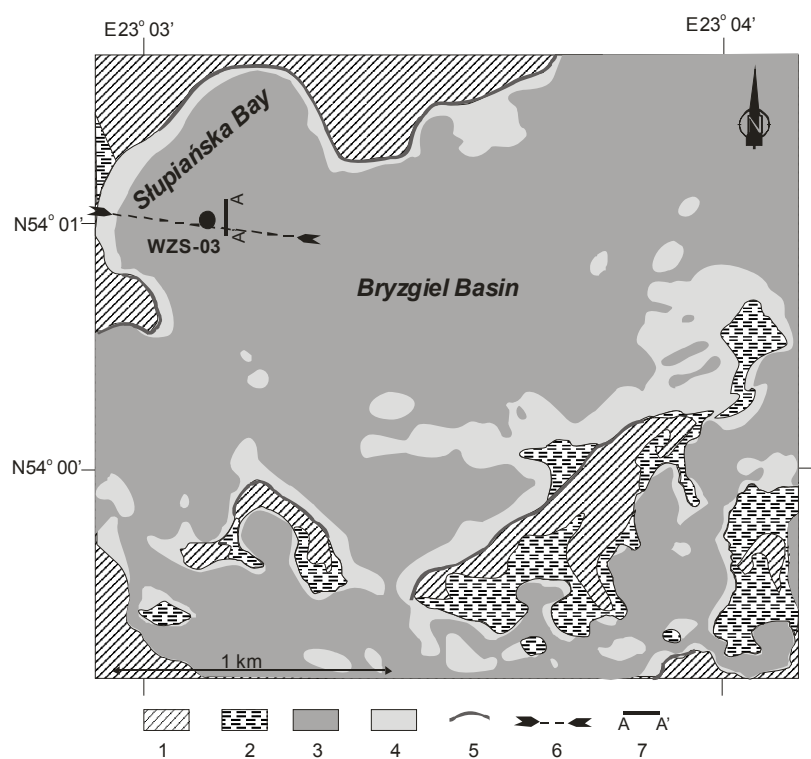

Fig. 3. Location of the WZS-03 borehole with simplified geological sketch of surrounding of Słupiańska Bay. 1 - glacial sediments; 2 - peat; 3 - calcareous gyttja (profundal); 4 - lacustrine chalk (littoral); 5 - zone with clastic sedimentation (out of scale); 6 - bathymetric profile; 7; - seismic profile.

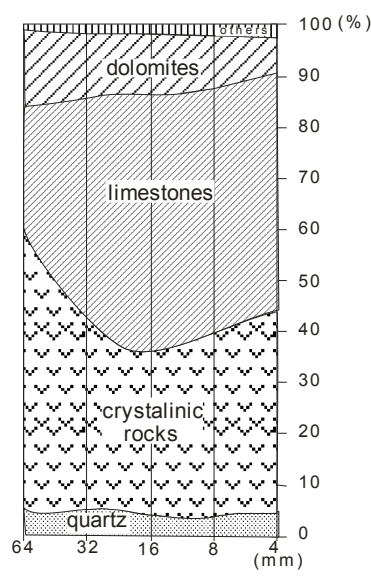

Fig. 4. Petrographic composition of lacustrine gravels from Słupiańska Bay in percent of the number of clasts, taking each grain-size class as 100 percent.

lacustrine gravels from the surrounding of Słupiańska Bay are carbonate rocks (Fig. 4). There are mainly lower Paleozoic limestones $(33.3$ - 49.8\%) and Devonian dolomites $(7-13.4 \%)$, but crystalline rocks as well as sandstone and quartzite are also observed. Such petrographic composition of gravels is typical for Late Quaternary sediments in NE Poland. Carbonate materials from these gravels and diamicton are the main source of calcium carbonate in the lake water and finally in lacustrine sediments of Wigry lake.

Maximum water depth in Słupiańska Bay is $29 \mathrm{~m}$. As shown on the bathymetric (Fig. 5) and seismic profiles, the bottom is rather flat and the sediment cover is $3.5-$ $5.6 \mathrm{~m}$ thick. The nearshore shallows are 10-100 meters wide; lacustrine chalk occurs there. It is a rock of white, white-grayish or beige color, with varied size of grains, mainly of silt, sand or clay fractions. It contains more than $80 \%$ of $\mathrm{CaCO}_{3}$ and a few percent of organic substance. Top part of the chalk, several centimeters thick, is often more coarse-grained and without silt-clay fraction.
A.
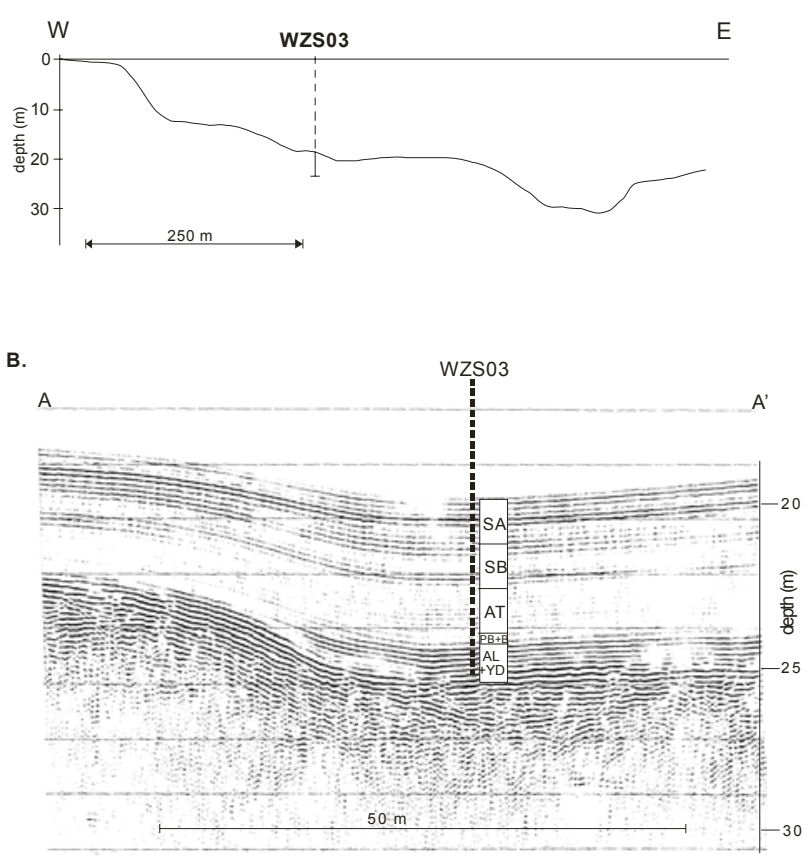

Fig. 5. A - Bathymetric profile, B - Seismic profile witch chronozones.

The lithology of the calcareous gyttja will be described further, together with the description of the WZS-03 core. The drilling was located in profundal zone at the point of depth of $18.2 \mathrm{~m}$; The distance from the lake shore was about $270 \mathrm{~m}$, and from the slope of the nearshore bank $180 \mathrm{~m}$ (Figs 3 and 5).

\section{METHODS}

Physical properties of water and content of oxygen (Fig. 2) were determined by a multiparameter water quality analyzer (YSI model 6920). The analysis of sediments from WZS-03 drilling comprised the determination of water contents (obtained by drying at $110^{\circ} \mathrm{C}$ ) and volume density (Fig. 6). In dry residue, the content of $\mathrm{CaCO}_{3}$ was determinated by Scheibler's volumetric method and organic matter as loss of ignition at $550^{\circ} \mathrm{C}$ after $4 \mathrm{~h}$. The analysis of trace metals TM involved decomposition of solid samples with concentrated nitric acid (65\%) at a pressure of $30 \mathrm{~atm}$ and a temperature of $200^{\circ} \mathrm{C}$ with the use of a microwave mineralizer Perkin Elmer. The diluted solutions were analyzed with the use of mass spectrometry with inductively coupled plasma (ICP-MS Perkin Elmer ELAN 6100). For determining trace metals in the top part of the profile, an additional core was taken with a gravitational sampler at the depth $0-0.4 \mathrm{~m}$.

\section{RESULTS}

The $5.26 \mathrm{~m}$ long profile of lacustrine sediments was received from the drilling WZS-03. The profile is continuous, without any traces of sedimentation break. In its lowermost part $(5.0-5.26 \mathrm{~m})$, dark lacustrine sandy mud with a low amount of $\mathrm{CaCO}_{3}(9.1-19 \%)$ and $4-5 \%$ of organic matter occur (Fig. 6). It contains also a small amount of plant detritus. Prevailing components of this 


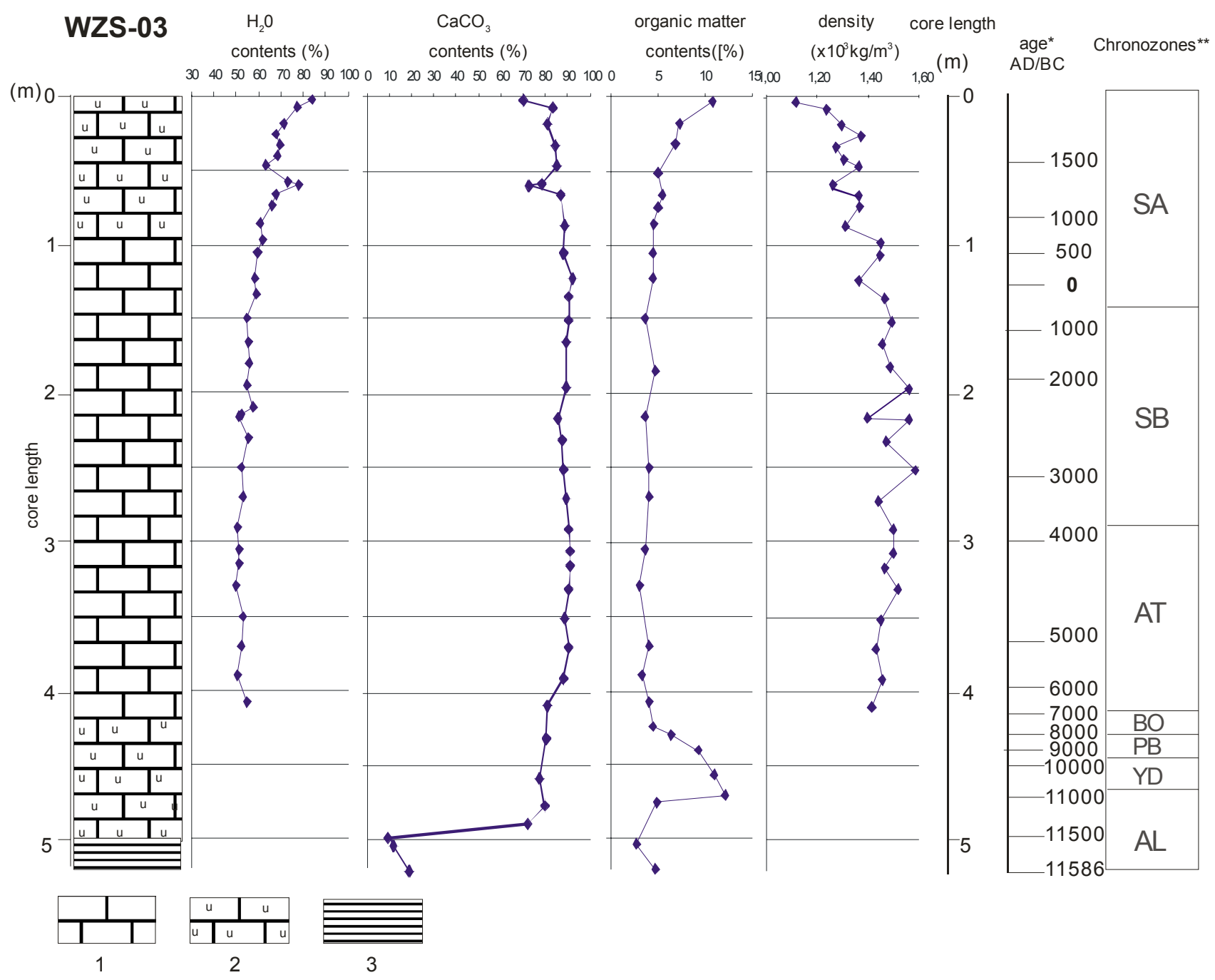

Fig. 6. Main lithological features of WZS-03 core. 1 - lacustrine chalk, 2 - calcareous gyttja; 3 - sandy muds. Age AD/BC after Piotrowska et al. (2007), Chronozones according Mangerud et al. (1974) in interpretation of Kupryjanowicz (2007).

mud are quartz grains in fraction lower than $0.06 \mathrm{~mm}$ $(55-80 \%)$. Admixtures of grains in fraction $0.06-$ $0.5 \mathrm{~mm}(9-33 \%), 0.5-2 \mathrm{~mm}(0.2-7.9 \%)$, and in coarser than $2 \mathrm{~mm}(0.1-6 \%)$ are also observed. The coarsest fractions consist of quartz, granitoids as well as limestone grains, which are indicative of fluvioglacial or glacial sediments in the underground of lake basin (Rutkowski et al., 2002a).

Upwards the profile $(4.2-5.0 \mathrm{~m})$ the amount of calcium carbonate radically increases (from 71.8 in the base, to $80.3 \%$ in the top of this interval). The content of organic matter oscillates from 4 to $13 \%$ and the sediments are represented by dark-grey calcareous gyttja.

The main part of the profile $(0.86-4.2 \mathrm{~m})$ consists of rather monotonous, very fine-grained and plastic, whitebeige lacustrine chalk. Lamination of sediment does not occur, only some darker, grey, few millimeters thick streaks with unsharp borders can be observed in the interval $1.05-2.15 \mathrm{~m}$. The content of water in this sediment is $50-60 \%$, the amount of $\mathrm{CaCO}_{3}$ reaches $85-92 \%$ of the dry residuum. The content of organic matter is $4-5 \%$, and volume density of the lacustrine chalk fluctuates from 1.34 to $1.52 \times 10^{3} \mathrm{~kg} / \mathrm{m}^{3}$.
Moving upwards along the profile, in the interval $0.83-0.10 \mathrm{~m}$, a progressive decrease of $\mathrm{CaCO}_{3}$ content (up to $80 \%$ ) and increase of water content (up to $75 \%$ ) is observed. The content of organic matter also slightly increases up to $7 \%$. The lacustrine chalk becomes darker in color and jellylike in consistency. Volume density of this sediment oscillates from 1.22 to $1.37 \times 10^{3} \mathrm{~kg} / \mathrm{m}^{3}$. In the interval $0.60-0.63 \mathrm{~m}$, an insert of semi-fluid, darkgrey calcareous gyttja with $78 \%$ of water and $72 \%$ of calcium carbonate occurs.

In the topmost part of the profile $(0-0.10 \mathrm{~m})$, lacustrine chalk is replaced by green to dark-grey, liquid, calcareous gyttja (Fig. 6) with high water content $(84 \%)$ and volume density of ca. $1.1 \times 10^{3} \mathrm{~kg} / \mathrm{m}^{3}$. The content of calcium carbonate decreases to $70 \%$, and the amount of organic matter increases to $10.9 \%$.

The lacustrine deposits from the drilling WZS-03 represent succession which is typical for postglacial lakes on the Polish Lowland. Sandy muds with plant detritus and admixture of sand and gravel observed in the base of the profile are characteristic for the lake forming stage (Stasiak, 1971; Więckowski, 1988). Fine-grained carbonate deposits, mainly lacustrine chalk, typical for Słupiańska Bay (Rutkowski et al., 2002), are connected with the 

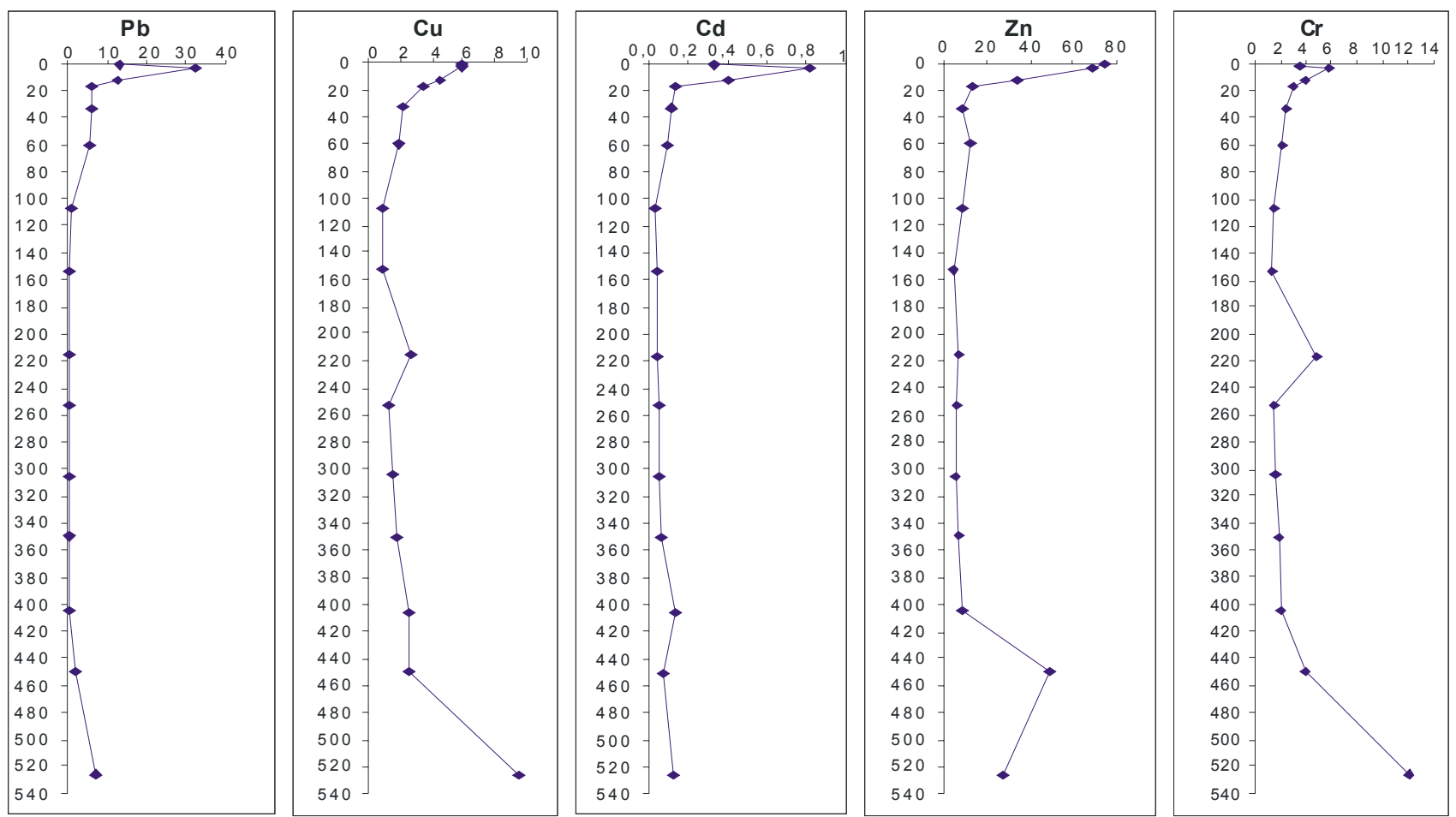

Fig. 7. Trace metals in sediments of WZS-03 core. All values in ppm.

period of calm sedimentation in profundal zone mainly in oligotrophic lakes. The decrease of calcium carbonate content and darkening of the color of sediments in the uppermost part of the profile is connected with deteriorating oxygenation conditions and increasing trophy of the lake, which indicate aging of the lake.

In the studied core, the amount of 20 trace metals (TM) was determined, and for five of them, the results are given in Fig. 7. Changes of these metal content over the length of the profile led to the distinction of its five parts. The lowest part is represented by sandy muds with higher content of TM (e.g. Co 4.4 ppm, Cr 12.2 ppm and $\mathrm{Zr} 13.1 \mathrm{ppm})$. The middle part of the profile $(4.0-1.0)$ contains small amounts of TM, the lowest and the least varied in the whole profile. For example, the content of $\mathrm{Cd}$ is most often 0.03-0.06 ppm, Co 0.3-0.8 ppm and $\mathrm{Ni}$ 1.4-2.8 ppm and $\mathrm{Pb} 0.3-0.4 \mathrm{ppm}$. Slightly higher amount of $\mathrm{Cu}$ and $\mathrm{Zn}$ in the sample taken from the depth of $2.2 \mathrm{~m}$ (Fig. 7) can be connected with the defect of the apparatus.

Above that, at the depth 0.6-0.2, the amount of TM is clearly, although slightly higher, and it is approximately twice as big as in the middle part of the core. The highest amount of TM is found in the upper part of the core (above $0.15 \mathrm{~m}$, but most often in the interval $0.05-$ $0.1 \mathrm{~m}$ ). The amounts of $\mathrm{Zn}$ and $\mathrm{Pb}$ are respectively ca 190 and 80 times higher than those in the middle part of the profile. It applies also to $\mathrm{Cd}$ (20 times) and $\mathrm{Cr}$ and $\mathrm{Cu}$ (4 times).

Particularly interesting is the decrease of the content of some TM in the uppermost part of the core (interval 0$0.5 \mathrm{~m})$. It is most prominent for $\mathrm{Pb}$ and $\mathrm{Cd}$ which are present in amounts 2.5 times smaller than in the lower part of the core. The amount of other elements: $\mathrm{Zr}$, As,
$\mathrm{Ni}, \mathrm{Cr}$ and $\mathrm{Co}$ is also smaller, whereas the content of $\mathrm{Cu}$ and $\mathrm{Zn}$ does not change.

High content of TM in sandy muds is connected with the admixture of crystalline rocks and an intensive surface washout. The middle part of the profile was formed in the period when the terrain was fully covered by forest. Slow increase of TM content in the interval $0.6-0.2 \mathrm{~m}$ was caused by deforestation and increase of agricultural activity. The same factors, and first of all the increase of the industrial activity caused the sudden increase of TM content. The same is found by Migaszewski et al. (2003) and Prosowicz (2006). The historical data indicate that it happened around $1960-1990$. Decrease of the amount of $\mathrm{TM}$ in the last $5 \mathrm{~cm}$ of profile is connected with the decrease of the industrial and agricultural activity after the year 1990 .

\section{CONCLUSIONS}

At the end of last cold period (glaciations) basin of Wigry Lake was filled with blocks of dead ice. On their surface, clastic sediments were deposited, on some places covered by land peat (Więckowski, 1988; Stasiak, 1971). Dead ice melting started in Allerøde. In this period, in the place of Stupiańska Bay there was a shallow, oligotrophic reservoir, in which sandy muds with carbonate and organic matter admixture were deposited. These deposits to a great extent resemble clays, underlying lacustrine sediments described by Stasiak (1971).

Wigry Lake as a deep water reservoir was formed between Younger Dryas and Holocene, when dead ice blocks in the substrate were completely melted. In the same time the clastic sedimentation was replaced by carbonate one, which lasts till now. The very fine-grain 
sediments indicate that the sedimentation proceeds in profundal conditions (Rutkowski et al., 2002) with only minor influence of littoral zone.

The distinct rise of lake trophy, expressed in an increase of organic matter admixture and decrease of $\mathrm{CaCO}_{3}$ amount in the sediments took place ca. 1200 years cal BP ago, i.e. around $800 \mathrm{AD}$ (at the depth $1 \mathrm{~m}$ ). An acceleration of this process takes place at the depth $0.1 \mathrm{~m}$.

In seismic profiles from profundal deposits of Wigry lake, a characteristic pattern of weak and strong reflections could be observed, which could be correlated in almost the whole lake. It seems that these reflections may be important seismostratigraphic horizons, or even chronohorizons. Pollen analysis (Kupryjanowicz, 2007) and radiocarbon dating (Piotrowska et al., 2007) allows to correlate the seismic profiles with Pleistocene and Holocene stratigraphy.

Lithological analysis of deposits from drilling WZS03 shows that there is a continuous, undisturbed profile which is suitable for interdisciplinary, comparison investigations, such as sedimentary rate and stable isotopes, pollen and Cladocera stratigraphy (Kupryjanowicz, 2007; Zawisza and Szeroczyńska, 2007) and diatoms succession (Witkowski et al., in press), seismostratigraphy and human activity.

\section{ACKNOWLEDGEMENTS}

The authors wish to express their thanks to the Institute of Geography and Spatial Organization PAN in Torun for drilling and to the staff of the Wigry National Park for the logistics help. This work has been supported by the Faculty of Geology, Geophysics and Environmental Protection AGH, grants: 10.10.140.928 - J. Rutkowski (in 2003-2004 y.), 11.11.140.458 - K. Król and 11.11.140.251 - J. Szczepańska.

\section{REFFERENCES}

Bajkiewicz-Grabowska E, 1992. Warunki odpływu i wymiana wód w jeziorach (Discharge and exchange conditions of water in the lakes). In: Zdanowski B, ed., Jeziora Wigierskigo Parku Narodowego. Stan eutrofizacji i kierunki ochrony. PAN. Kom. Naukowy „Człowiek i środowisko” Zeszyty Naukowe 3: 25-34.
Kamiński M, 1999. Lake Wigry - the lake ,adopted” by the International Association of Theoretical and Applied Limnology (SIL) „Lake Adoption” Project. Polish Journal of Ecology 57 (2): 215224.

Kupryjanowicz M, 2007. Postglacial development of vegetation in the vicinity of the Wigry Lake. Geochronometria 27: 53-66, DOI 10.2478/v10003-007-0018-x.

Migaszewski ZM, Gałuszka A and Pasławski P, 2003. Baseline versus background concentrations o trace elements in sediments of Lake Wigry, NE Poland. Limnological Review 3 (2003): 165-171.

Piotrowska N, Hajdas I, Bonani G, 2007. Construction of the calendar time scale for Lake Wigry (NE Poland) sediments on the basis of radiocarbon dating. Radiocarbon 49(2): in print.

Prosowicz D, 2006. Metale śladowe i ich chemiczne formy wiązania w osadach dennych jeziora Wigry (Trace metals and their chemical fractions in bottom sediments of Wigry lake). $\mathrm{PhD}$ thesis, University of Science and Technology, Kraków: 129 pp.

Prosowicz D and Helios-Rybicka E, 2002. Trace metals in recent bottom sediments of Lake Wigry (Bryzgiel Basin). Limnological Review 2 (2002): 323-332.

Rutkowski J, 2004. Osady jeziora Wigry (Sediments of the Wigry Lake). Augustowsko Suwalskie Towarzystwo Naukowe. Rocznik Augustowsko Suwalski IV: 18-36.

Rutkowski J, Król K, Krysztofiak L and Prosowicz D, 2002. Recent sediments of the Wigry Lake (Bryzgiel Basin). Limnological Review 2 (2002): 353-362.

Rutkowski J, Rudowski S, Pietsch K, Król K and Krzysztofiak L, 2002a. Sediments of Lake Wigry (NE Poland) in the light of highresolution seismic (seismoacoustic) survey. Limnological Review 2/2002: 363-371.

Rutkowski J, Pietsch K, Król K, Rudowski S, and Krzysztofiak L, 2005. High-resolution seismic survey in the Wigry Lake (NE Poland). Peribalticum IX: 147-162.

Stasiak J, 1971. Geneza basenów sedymentacyjnych na obszarach sandrowych (Genesis of sedimentation basins on outwash plains). Zeszyty Problemowe Postęów Nauk Rolniczych 107: 103-112.

Więckowski K, 1988. Stosunki wodne i ewolucja systemu jezior (Water relations and evolution of lake system). In: Kostrowicki SA, ed., Studium geoekologiczne rejonu jezior wigierskich. PAN Instytut Geografii i Przestrzennego Zagosodarowania. Prace geograficzne 147: 31-44.

Witkowski A, Kierzek A, Bąk M and Paśnicka K, in press. Rekonstrukcja warunków sedymentacji w Zatoce Słupiańskiej Jeziora Wigry w świetle analizy diatomologiczosadó rdzenia WZS-03 (Reconstruction of sedimentation conditions in the Słupiańska Bay (Lake Wigry) as elucidated by diatomological analysis of sediments core WZS-03). Prace Komisji Paleogeografii Czwartorzędu PAU IV(2005).

Zawisza E and Szeroczyńska K, 2007. The development history of Wigry Lake as shown by subfossil Cladocera. Geochronometria 27: 67-74, DOI 10.2478/v10003-007-0021-2.

Zdanowski B, ed., 1992. Jeziora Wigierskigo Parku Narodowego. Stan eutrofizacji i kierunki ochrony (Lakes of Wigry National Park. Trophic status and protection directions). PAN. Kom. Naukowy „Człowiek i środowisko” Zeszyty Naukowe 3: 249pp. 